\title{
STUDI PEMANFAATAN HUMA BETANG TUMBANG MANGGU SEBAGAI SUMBER PEMBELAJARAN OLAHRAGA TRADISIONAL DI KALIMANTAN TENGAH
}

\author{
Jurdan Martin Siahaan ${ }^{1}$, Sundhari ${ }^{2}$ \\ Universitas PGRI Palangkaraya \\ jordanunj@gmail.com
}

\begin{abstract}
Abstrak
Penelitian ini diarahkan kepada Masyarakat Kalimantan tengah bertujuan untuk mengolahragakan masyarakat dan memasyarakatkan olahraga guna untuk menyehatkan kehidupan bangsa pada umumnya dan membuat masyarakat palangkaraya bugar dan cinta akan budaya kalimantan tengah pada khusunya. Penelitian ini dapat dijadikan sebagai salah satu pedoman atau pertimbangan dalam sumber belajar Olahraga Rekreasi SD, SMP, SMA, Perguruan Tinggi dan Umum.

Penelitian ini menggunakan metode Observasi dan Wawancara. Data instrumen penelitian didapat oleh beberapa pakar ahli dibidangnya yang kemudian di Observasi. Pengambilan data dalam penelitian ini dilakukan melalui wawancara yang mendalam, observasi, kuisioner. Analisis data hasil pengamatan dengan kualitatif deskriptif menunjukkan bahwa Rumah Betang Tumbang Manggu sangat menunjukkan ciri khas Dayak dan mengangkat kearifan lokal Kalimantan Tengah. Seperti permainan tradisional, Tarian, Musik, Alat Musik, Lagu Daerah, Wisata Rumah Adat, Wisata Peralatan Kuno, wisata rumah panggung dan wisata Air. Dengan demikian dapat disimpulkan bahwa rumah betang tumbang manggu sangat cocok dijadikan sumber belajar Olahraga Tradisional Untuk Masyarakat karena banyak hal positif yang didapat dari permainan trdisional Kalimantan Tengah.
\end{abstract}

\section{Kata Kunci : Olahraga Tradisional, Rumah Betang, Tumbang Manggu}

\section{Abstract}

This research is directed at the people of Central Kalimantan aiming at sports and promoting the sport of society in order to nourish the life of the nation in general and make the Palangkaraya community fit and love the Central Kalimantan culture in particular. This research can be used as one of the guidelines or considerations in learning resources for Recreational Sports in elementary, middle, high school, universities and general.

This research uses the Observation and Interview method. The research instrument data was obtained by several experts in their field which were then observed. Data collection in this study was carried out through in-depth interviews, observations, and questionnaires. Analysis of observational data with descriptive qualitative shows that the House of Betang Tumbang Manggu strongly shows Dayak characteristics and elevates local wisdom of Central Kalimantan. Such as traditional games, dance, music, musical instruments, folk songs, traditional house tours, ancient equipment tours, stage house tours and water tours. Thus, it can be concluded that the fallen home of Manggu betang is very suitable as a source of learning Traditional Sports for the Community because of the many positive things gained from the traditional game of Central Kalimantan.

Keywords: Traditional Sports, Huma Betang, Tumbang Manggu

Dipublikasikan Oleh :

UPT Publikasi dan Pengelolaan Jurnal

Universitas Islam Kalimantan Muhammad Arsyad Al-Banjari Banjarmasin 


\section{RINGKASAN}

Dalam rangka memperbaiki persepsi siswa terhadap Olahraga Tradisional maka peran guru Olahraga dan penggalian Olahraga Tradisional sangat penting demi tercapainya tujuan pemerintah yaitu mengolahraga masyarakat dan memasyarakatkan Olahraga.

Huma Betang Tumbang Manggu merupakan salah satu saksi Olahraga Tradisional Kalimantan Tengah, karena pada tahun 1894 terjadi peristiwa Rapat Tumbang Manggu yang menyatukan seluruh anak suku Dayak se Kalimantan Tengah. Sehingga perlu dilakukan sebuah studi tentang pemanfaatan Huma Betang Tumbang Manggu sebagai Sumber Pembelajaran Olahraga Tradisional lokal di Kalimantan Tengah, agar kearifan lokal suku dayak kalimantan tengah tetap terjaga.

Huma Betang Tumbang Manggu bisa dijadikan sarana untuk melestarikan olahraga tradisional dan menjadi salah satu pusat rekreasi di Kalimantan Tengah. Olahraga tradisional merupakan salah satu peninggalan budaya nenek moyang yang memiliki kemurnian dan corak tradisi setempat. Indonesia dikenal memiliki kekayaan budaya tradisional yang sangat beraneka ragam. Namun seiring dengan semakin lajunya perkembangan teknologi di era globalisasi ini, kekayaan budaya tradisional semakin lama semakin tenggelam. Semuanya mulai tenggelam seiring dengan pengaruh budaya asing, maraknya permainan playstation, game watch, computer game, dan lain-lain.

Banyak permainan juga olahraga yang menghilang disebabkan faktor dari dalam maupun luar diri Negara kita ini. Pengaruh teknologi yang menjadi pendukung perkembangan Globalisasi ini juga menjadi faktor pendorong hilangnya budaya kita sendiri. Budaya atau tradisi di Indonesia seperti permainan dan olahraga tradisional menjadi perhatian saya karena banyak anak anak di Indonesia yang bahkan tidak tau cara memainkannya serta aturan aturannya. seni adalah budaya yang dapat dipertahankan karna seni dapat membentuk ruang sendiri dalam perkembangan globalisasi. Aktivitas yang dilakukan pada waktu senggang (lapang) yang bertujuan untuk membentuk, meningkatkan kembali kesegaran fisik, mental, pikiran dan daya rekreasi (baik secara individual maupun secara kelompok) yang hilang akibat aktivitas rutin sehari-hari dengan jalan mencari kesenangan, hiburan dan kesibukan yang berbeda dan dapat memberikan kepuasan dan kegembiraan yang ditujukan bagi kepuasan lahir dan batin manusia".

Metode penelitian yang digunakan adalah metode deskriptif, dengan menggunakan data primer dan data sekunder. Data primer diperoleh melalui wawancara, pengamatan/observasi dan dokumentasi sedang data sekunder diperoleh dari dokumentasi/publikasi oleh berbagai instansi/lembaga pemerintah dan non pemerintah. Setelah data dikumpulkan, selanjutnya dianalisis dengan menerapkan model analisis interaktif yaitu reduksi data, verifikasi data, penyajian data, dan penarikan kesimpulan serta penulisan laporan.

\section{LATAR BELAKANG}

Pembelajaran Olahraga Tradisional secara umum dinilai dan dianggap oleh siswa tidak terlalu penting Karena guru Olahraga hanya menekankan kepada siswa untuk berolahraga. Sebenarnya proses pendidikan khususnya pengajaran Olahraga Tradisional, ibarat mengajak peserta didik menengok ke belakang dengan tujuan melihat ke depan. Sehingga dapat disimpulkan bahwa dengan mempelajari nilai-nilai kehidupan masyarakat di masa lampau, diharapkan siswa atau peserta didik mencari atau mengadakan seleksi terhadap nilai-nilai kompleks di masa kini maupun yang akan datang (Sirnayatin, 2017). Maka dari itu, guru Olahraga dan Rekreasi harus mempunyai wawasan yang luas serta mendalam dan mempunyai motivasi yang tinggi dalam proses pembelajaran Olahraga sehingga makna yang terkandung dalam mata pelajaran Olahraga dapat tersampaikan.

Guru Olahraga mempunyai peran yang penting dalam pengembangan karakter siswa sebagaimana yang tertuang dalam Permen No.16 Tahun 2007 tentang Standar Kualifikasi dan Kompetensi Guru menyatakan bahwa “...guru Olahraga harus menguasai struktur keilmuan, ruang lingkup, dan objek Olahraga; membedakan pendekatan-pendekatan Olahraga; menguasai materi Olahraga Tradisionalyang luas dan mendalam serta menunjukkan manfaat mata pelajaran Olahraga". Selain itu, guru Olahraga harus membantu dalam proses internalisasi nilai-nilai positif di dalam diri siswa yang tidak bisa digantikan oleh media pendidikan secanggih apapun (Tukidi, 2011)

Dipublikasikan Oleh :

UPT Publikasi dan Pengelolaan Jurnal

Universitas Islam Kalimantan Muhammad Arsyad Al-Banjari Banjarmasin 
Kenyataan pembelajaran Olahraga di Sekolah Menengah Atas (SMA) yang ada di Kalimantan Tengah, sudah berjalan dengan baik dan efektif sesuai dengan tujuan pembelajaran Olahraga yang ingin dicapai yaitu untuk mengolahraga masyarakat dan memasyarakatkan Olahraga, mencerdaskan dan membentuk karakter bangsa serta memberikan nilai-nilai moral terhadap generasi masa kini. Apalagi jika menggunakan data normatif bahwa setiap kali kenaikan kelas hampir semua siswa dapat melampaui nilai KKM (Kriteria Ketuntasan Minimal), walaupun sangat diyakini bahwa nilai KKM bukan jaminan gambaran kemampuan yang sesungguhnya (Sayono, 2017).

Namun masih ada kekurangannya, yakni keengganan guru Olahraga menggunakan sumber-sumber Olahraga Tradisional lokal dalam pembelajaran Olahraga. Kondisi ini juga didukung oleh kurangnya kreatifitas guru untuk memanfaatkan sumber Olahraga Tradisional lokal di Provinsi Kalimantan Tengah yang tersedia banyak untuk di pakai dan dipelajari. Padahal penerapan Olahraga Tradisionallokal juga membawa perubahan positif pada diri siswa dengan mengenalkan Olahraga Tradisional lokal antara lain tumbuhnya nasionalisme, kesadaran memainkan Olahraga Tradisional, Rekreasi Lokal, berpikir kritis, gotong royong, dan sebagainya (Wijayanti, 2017). Dengan berlakunya Kurikulum 2013, maka penggunaan Olahraga Tradisionallokal mempunyai ruang yang besar untuk diimplementasikan.

Tenggelamnya budaya Olahraga tradisional tersebut tentunya merupakan suatu keprihatinan bagi kita semua. Jika generasi saat ini tidak berusaha melestarikan maka lambat laun budaya tradisional akan semakin tenggelam dan suatu saat akan punah, sehingga identitas bangsa Indonesia sebagai bangsa yang berkebudayaan tinggi akan hilang.

Penyebab tenggelamnya budaya tradisional tersebut tentunya terdiri dari berbagai macam, seperti:

1. Kurangnya sosialisasi olahraga tradisional kepada masyarakat;

2. Tidak adanya minat masyarakat untuk menggali kekayaan tradisional;

3. Tidak ada minat melombakan secara berjenjang, berkelanajutan, dan berkesinambungan.

Jika olahraga rekreasi semakin diminati dan semakin dikenal oleh masyarakat banyak maka otomatis daerah tersebut akan dikenal dan akan dikunjungi oleh masyarakat banyak, dan menjadi salah satu tujuan wisata baru dan menarik di Kalimantan Tengah.

Dari uraian di atas, maka perlu dilakukan Penelitian pemanfaatan Huma Betang Tumbang Manggu sebagai Sumber Pembelajaran Olahraga TradisionalLokal di Kalimantan Tengah.

\section{TINJAUAN PUSTAKA}

Betang (dalam bahasa Ot Danum Behtang) ialah rumah yang memiliki banyak keistimewaan yang berbeda dari rumah-rumah pada umumnya. Betang artinya Rumah Panjang merupakan rumah tinggal tradisional masyarakat Dayak Ngaju, Kalimantan Tengah. Betang mempunyai nilai historis dan sakral merupakan bentuk permukiman awal dan mata rantai kebudayaan masa lampau, kini dan masa mendatang (Hamidah dan Garib, 2016). Dalam penelitian dan kajian yang dilakukan Suwarno (2017), Masyarakat Dayak sangat menjujung budaya huma betang dan budaya ini sangat mengakar dalam kehidupan mereka. Makna yang terkandung dalam budaya huma betang yang paling kental adalah komunalisme, yang di dalamnya terkandung nilai kebersamaan, tolong menolong, egaliter, kekeluargaan, mufakat dan hidup beradat. Pola-pola tersebut mengakar terutama sekali pada masyarakat Dayak pedalaman.

Namun bukan berarti masyarakat Dayak perkotaan terbebas dari ikatan tersebut, dalam beberapa kasus kehidupan masyarakat Dayak perkotaan masih meresapi budaya betang.

Bisa dinyatakan bahwa Betang Tumbang Manggu merupakan sebuah karya besar dalam dunia arsitektur yang sekaligus memiliki nilai Olahraga Tradisional dan Rekreasi. Hal spesifik di bidang arsitektur adalah keunikan, kelangkaan, kejamakan dan hal-hal lain yang berhubungan dengan makna kultural dari masyarakat termasuk didalamnya religi (Hamidah dan Garib, 2014). Betang Tumbang Manggu ini juga menjadi saksi Olahraga Tradisional sebuah peristiwa besar yang menyatukan seluruh anak suku Dayak di Kalimantan. Maka sangat disayangkan jika saksi bisu dari peristiwa berOlahraga Tradisionaltersebut rusak/hancur dan tidak dapat difungsikan dan dimanfaatkan dengan baik untuk generasi sekarang dan generasi yang akan datang.

Olahraga tradisional merupakan permainan asli rakyat sebagai aset budaya bangsa yang memiliki unsur olah fisik tradisional. Permainan rakyat yang berkembang cukup lama ini perlu dilestarikan, karena selain 
sebagai olahraga hiburan, kesenangan, dan kebutuhan interaksi sosial, olahraga ini juga mempunyai potensi untuk meningkatkan kualitas jasmani bagi pelakunya.

Olahraga tradisional semula tercipta dari permainan rakyat sebagai pengisi waktu luang. Karena permainan tersebut sangat menyenangkan dan tidak membutuhkan biaya yang sangat besar, maka permainan tersebut semakin berkembang dan digemari oleh masyarakat sekitar. Permainan ini dilakukan dan digemari mulai dari anak-anak sampai dengan dewasa, sesuai dengan karakter permainan yang dipakai. Beberapa permainan rakyat yang sudah cukup dikenal oleh seluruh lapisan masyarakat di Indonesia dan menjadi olahraga tradisional adalah seperti egrang, terompah panjang, patok lele, gobak sodor (hadang), sumpitan, gebuk bantal, gasing, lari balok, tarik tambang, benteng, dagongan, panjat pohon pinang, sepak raga, lomba perahu, lompat batu nias, karapan sapi, dan lain-lain.

Olahraga tradisional merupakan salah satu peninggalan budaya nenek moyang yang memiliki kemurnian dan corak tradisi setempat. Indonesia dikenal memiliki kekayaan budaya tradisional yang sangat beraneka ragam. Namun seiring dengan semakin lajunya perkembangan teknologi di era globalisasi ini, kekayaan budaya tradisional semakin lama semakin tenggelam. Semuanya mulai tenggelam seiring dengan pengaruh budaya asing, maraknya permainan playstation, game watch, computer game, dsb.

Permainan tradisional menurut Balai Pengembangan Pendidikan Luar Sekolah dan Pemuda (BPPLSP):

Permainan tradisional merupakan hasil penggalian dari budaya sendiri yang didalamnya banyak mengandung nilai-nilai pendidikan karena dalam kegiatan permainannya memberikan rasa senang, gembira, ceria pada anak yang memainkannya. Selain itu permainannya dilakukan secara berkelompok sehingga menimbulkan rasa demokrasi antar teman main dan alat permainan yang digunakan pun relatif sederhana (BPPLSP, 2006) .

Pada umumnya, permainan tradisional memiliki ciri kedaerahan asli sesuai dengan tradisi budaya setempat. Oleh karena itu, dalam pelaksanaannya, unsur-unsur permainan rakyat dan permainan anak sering dimasukkan dalam permainan tradisional. Dimungkinkan juga untuk memasukkan kegiatan yang mengandung unsur seni seperti yang biasa kita sebut dengan seni tradisional. Permainan tradisional memiliki ciri yang punya unsur tradisi dan berkaitan erat dengan kebiasaan atau adat suatu kelompok masyarakat tertentu. Kegiatan yang dilakukan harus mengandung unsur fisik nyata yang melibatkan kelompok otot besar dan juga mengandung unsur bermain sebagai landasan maksud dan tujuan dari kegiatan tersebut.

Selanjutnya olahraga tradisional sangat dekat hubungannya dengan rekrasi karna disaat kita memainkan olahraga tradisional makan perasaan kita senang dan gembira. Menurut Bovy dan Lawson (1997) ada beberapa hal yang menjadi factor yang mempengaruhi rekreasi antara lain :

1. Faktor sosial ekonomi;

Pada masyarakat dengan kelompok social tertentu (elite) akan berbeda dengan rekreasi masyarakat pada umunya karena perbedaan fasilitas yang dimiliki.

2. Faktor jenis kelamin , usia dan keluarga;

Kegiatan rekreasi remaja putri mungkin berbeda dengan remaja putra dan berbeda pula dengan kegiatan reklreasi orang dewasa.

3. Faktor ketersediaan waktu luang;

4. Waktu luang penyelenggaraan rekreasi ibu rumah tangga akan berbeda dengan wanita pekerja.

5. Faktor pranata;

Berhubungan dengan pencapaian, besar dana yang dimiliki, perubahan sikap terhadap rekreasi.

6. Faktor perubahan teknologi;

Berhubungan dengan munculnya jenis-jenis rekreasi baru dan kemudahan pencapaian dengan fasilitas-fasilitas rekreasi dengan teknologi tinggi.

Menurut Wing Haryono dalam buku " Pariwisata Rekreasi dan Entertainment “ mengatakan bahwa kegunaan dari rekreasi adalah :

1. Untuk kesehatan, baik itu kesehatan tubuh maupun pikiran;

2. Untuk dapat membentuk atau membangun karakter;

Dipublikasikan Oleh :

UPT Publikasi dan Pengelolaan Jurnal

Universitas Islam Kalimantan Muhammad Arsyad Al-Banjari Banjarmasin 
3. Sebagai pencegah kriminalitas;

4. Sebagai sarana pendidikan moral;

5. Untuk hal-hal yang behubungan dengan ekonomi;

Tujuan Rekreasi

Adapun tujuan rekreasi antara lain :

1. Menciptakan dan membina hubungan manusia;

2. Mempertahankan kelestarian alam;

3. Mempertahankan nilai-nilai budaya;

4. Kesenangan dan kepuasan karena dapat memenuhi rasa ingin tahu/ bertualang;

5. Memulihkan kesehatan jasmani dan rohani;

Dengan mempelajari dan menghaayati semangat persatuan yang pernah terjadi di Betang Tumbang Manggu bisa didapatkan semangat mengangkat kembali permainan tradisional dayak dan menjadikan huma betang menjadi salah satu tempat rekreasi di Kalimantan Tengah.

\section{METODE}

Metodologi penelitian yang digunakan adalah penelitian kualitatif dengan pendekatan deskritif analisis. Metode deskriptif adalah suatu metode dalam meneliti status sekelompok manusia, suatu objek, suatu set kondisi, suatu sistem pemikiran ataupun suatu klas peristiwa. Tujuan dari penelitian deskriptif adalah untuk membuat deskripsi, gambaran, lukisan secara sistematis, faktual dan akurat mengenai fakta-fakta, sifat-sifat serta hubungan antara berbagai fenomena yang diteliti (Nazir, 2003).

Penelitian ini akan menggunakan data primer dan data sekunder. Data primer diperoleh melalui wawancara, observasi atau pengamatan langsung, dan dokumentasi. Wawancara dilakukan dengan informan atau narasumber yang terkait dengan tema penelitian ini adalah pihak pengelola (Dinas Pendidikan), masyarakat adat Desa Tumbang Manggu, guru Olahraga, dan siswa SMA Kota Palangka Raya dan Katingan. Dokumentasi yang dilakukan oleh peneliti menggunakan dokumentasi berupa pengambilan foto-foto, rekaman, catatan dan lain-lain.

Validitas data dilakukan dengan teknik triangulasi sumber, Triangulasi sumber yang dilakukan dalam penelitian ini adalah dengan membandingkan hasil pengamatan dengan hasil wawancara, kemudian membandingkan hasil wawancara dengan dokumen yang terkait dengan tema penelitian, sehingga dengan mengunakan triangulasi sumber ini akan mengarahkan peneliti dalam mengumpulkan data wajib untuk mengunakan beragam sumber data yang tersedia. Adapun data sekunder diperoleh dari pengelola Rumah Betang, instansi teknis terkait seperti Badan Pusat Statistik (BPS), Dinas Pendidikan Provinsi Kalimantan Tengah, Dinas Pendidikan Kabupaten Katingan ataupun sumber pendukung penting lainnya. Setelah data dikumpulkan, selanjutnya dianalisis dengan menerapkan model analisis interaktif yaitu reduksi data, verifikasi data, penyajian data, dan penarikan kesimpulan serta penulisan laporan.

\section{HASIL DAN PEMBAHASAN}

Dari hasil penelitian didapatkan data dilapangan bahwa Humah Betang Tumbang Manggu sanggat berkontribusi terhadap Olahraga Tradisional Di kalimantan Tengah, karena selalu ada Kegiatan Olahraga Tradisional setiap tahunya yaitu pada saat ulang tahun HBTM Ataupun ulang tahun Kabupaten Kapuas, kegiatan olahraga tradisional di HBTM antara lain:

\section{A. Terkait Dengan Olahraga Tradisional \\ 1. Manyipet (Menyumpit) \\ a. Nama permainan}

Perkataan Manyipet dalam bahasa Dayak Ngaju jika diterjemahkan kedalam Bahasa Indonesia berarti menyumpit. Dari nama tersebut dapat diketahui bhwa kegiatan utama permainan ini adalah menyumpit, yakni suatu kepandaian membidikkan anak sumpitan (damek) ke suatu sasaran dengan menggunakan sebuah sumpitan. Permaianan mentumpit sebagai suatu permainan guna melatih keterampilan biasanya dilakukan pada waktu siang hari.

Dipublikasikan Oleh :

UPT Publikasi dan Pengelolaan Jurnal

Universitas Islam Kalimantan Muhammad Arsyad Al-Banjari Banjarmasin 
b. Latar Belakang sosial budaya

Sumpitan adalah alat berburu dan alat perang yang dipunyai oleh orang dayak dari masa ke masa. Dalam lambang daerah kalimantan tengah juga disisipkan gambar sebuah sumpitan. Karna kedudukan yang penting dari sumpitan dalam kehidupan orang-orang dayak zaman dulu. Mandau, tameng, dan sumpitan merupakan seperangkat peralatan perang yang selalu dibawa para pendekar dayak kemanapun mereka pergi. Sumpitan merupakan senjata yang paling ditakuti lawan karna mempunyai kemampuan serang jarak jauh, yaitu bebrapa puluh meter dan dapat dilancarkan tanpa mengeluarkan bunyi. Jadi serangan sumpitan merupakan serangan jarak jauh yang tak berbunyi. Senjata sumpitan juga mempunyai racun yang disebut ipu pada ujung anak sumpitan yang disebut damek. Kadar racun ipu amat tinggi dan mampu membunuh dalam temppo beberapa detik atau beberapa menit saja.

c. Latar Belakang sejarah perkembangan

Yang melatarbelakangi perkembangan dan pertumbuhan permainan menyumpit ini adalah tuntutan kehidupan sehari-hari baik untuk kepentingan berburu atau berperang, dan kepandaian menyumpit ini harus ditempa hingga tercapai suatu tingkat keterampilan yang dapat diandalkan. Setelah orang dayak mengenl senjata api, sumpuitan muli terdesak. Orang mulai berlih ke senjata api. Sumpitan kemudian digunakan hanya untuk berburu burung atau binatang kecil lainnya. Kemudian sumpitan jarang diperoleh dan sumpitan menjdi barang antik. Sejalan dengan itu, anak-anak mengembangkan jenis sumpitan baru, yaitu yang dibuat dari buluh yang bernama tamiang. Buluh ini hanya mempunyi garis tengah hanya bebrapa centi meter dan mempunyai ruas yang anjang serta buku yang tipis, karena sumpitn berubah bentuk, anak sumpitan juga berubah bentuk. Kini anak sumpitan dibuat dari tanah liat yang lembek dibentuk berupa bola-bola kecil. Sasaranpun berubah yakni binatang kecil yang terdapat dipantai sungaisungai besar yang dangkal.

d. Deskripsi permaianan

Permainan menyumpit ini biasanya dapat dilakukan sendirian dan dapat dilakukan bersama-sama dalam bentuk pertandingan. Dan jika dimainkan dengan pertandingan maka jumlah peserta tergantung kepada jumlah peminatnya. Pemain biasanya laki-laki berusia antara 9-15 tahun. Kalau pertandingan dengn sumpitan biasanya pesertanya laki-laki dewasa.

e. Peralatan/perlengkapan permainan

Peralatan pokok permaianan ini adalah sebuah sumpitan serta beberapa buah anak sumpitan. Lapangan bermain tidak menuntut pengadaan secara khusus karna alam terbuka merupakan lapangan bermain yang telah tersedia.

f. Cara permaianan

a) Setiap haruslah mempunyai sebiah sumpitan. Sumpitan ini biasanya terbuat dari kayu besia (tabalien/ulin) yang merupakan sebuah silinder yang berlubang ditengahnya sehingga menjadi sebuah pipa. Panjang kira-kira 2 meter. Pada ujung sumpitan terdapat mata tombak. Manfaat mata tombak ini sebgai alat berburu binatang. Anak sumpitan hanya dibuat dari bambu yang diraut halus dan salah satunya diruncingkan. Pada ujung lainya dipasang kertas yang membentuk kerucut. b)Setelah masing-masing memegang pemain lalu bersama-sama mencari sasaran yang dianggap baik. Dalam hal ini sasaran yang sengaja disiapkan seperti pada perlombaan memanah tidak ada. Jarak antara penyumpit dan sasaran juga tidak terdapat ketentuan pasti/baku. Jarak tergantung pada tingkat kemahiran para pemain atau penyumpit. Semakain mahir maka jarak sasaran akan semakin kecil dan jauh. Kadang-kadang sasaran menyumpit tidak sama, msalnya kalau para pemain sepakat untuk menyumpit burung, maka mereka pergi ketempat yang banyak burung berkumpul, lalu disitu membagi giliran, seorang penyumpit lalu giliran penyumpit berikutnya. Kadang mereka juga bersepakat untuk mentumpit satu ekor burung, dan yang berhasil menjatuhkan maka dia yang jadi pemenangnya. Pada anak-anak dengan sumpitan dengan bulu tamiang, sasaran mereka adalah binatang melata amphibia yang disebut tempakul. Anak sumpitannya dari tanah liat. Pennetuan juara sama seperti diatas. c) Permaian ini bukanlah permaian yang rumit, pentahapannya 
hanya dua, yaitu tahap persiapan dan pertandingan. d) Sebegitu jauh belum diketahui konsekuensi menang-kalah, karna permaianan ini hanya lebih banyak bersifat memperagakan keterampilan. Jadi hanya sebutan juara atau jago itulah yang menjadi kebanggaan setiap pemenang.

\section{Sepak Sawut}

a. Nama permainan

Sepak sawut merupakan permainan tradisional yang banyak digemari oleh masyarakat bukan hanya kalangan muda tetapi banyak juga orang tua yang menggemari permainan yang satu ini terutama warga masyarakat Kalimantan. Sepak sawut yaitu sebuah permainan seperti permainan sepak bola pada umumnya. Namun yang membedakan dengan permainan sepak bola yaitu pada bola yang digunakan untuk bermain merupakan bola yang berapi.

b. Latar Belakang Sejarah

Dahulu, sepak sawut merupakan rangkaian ritual adat, dimainkan saat membuka ladang berpindah/saat menunggu jenazah (untuk umat Kaharingan). Sekarang olahraga rakyat itu secara rutin dimainkan pada setiap perayaan ulang tahun kabupaten atau provinsi di Kalteng. Dahulunya sepak bola yang satu ini dimainkan pada saat orang ingin membuka ladang berpindah. Karena kebanyakkan pada tempo dulu di Kalimantan hampir semua kegiatan dilakukan secara gotong-royong seperti membangun rumah, membuka ladang, menanam padi, memanen padi yang dilakukan secara bersama-sama atau dalam bahasa daerahnya "handep". Permainan sepak sawut sekarang sudah agak jarang kita temukan. Artinya permainan ini hampir langka hanya pada waktu-waktu tertentu saja kita dapat menyasikannya, misal pada perayaan ulang tahun Propinsi Kalteng, ulang tahun kabupaten, festival-festival budaya.

c. Cara Permainan

Bolanya dapat terbuat dari bongkahan sabuk kelapa tua yang telah kering dengan terlebih dahulu airnya dibuang lalu bongkahan tersebut direndam menggunakan minyak tanah. Tujuannya supaya minyak meresap kedalam serat-serat bola kelapa tersebut. Supaya lebih seru lagi permainan ini dimainkan pada malam hari. Ini memiliki keindahan tersendiri, karena penerangan hanya menggunakan lampu seadanya dan cahaya kebanyakan bersumber dari bola api yang dimainkan. Peraturan main juga hampir sama, tidak berbeda jauh dengan main sepak bola pada umumnya yang terdiri dari dua gawang, gawang kita dan gawang musuh. Satu tim terdiri dari lima orang pemain. Lapangan yang digunakan tidak berbeda jauh dengan luas lapangan bola basket. Pertandingan dipimpin oleh seorang wasit. Siapa yang banyak memasukkan bola ke gawang lawan maka tim tersebut yang dinyatakan sebagai pemenang dalam lomba. Satu tim hanya diperkuat lima orang dengan ukuran arena seluas lapangan bola basket.

\section{Bagasing}

Bagasing ini seperti gasing pad umumnya, tetapi gaing disini terbuat dari batang atau pohon karet. Biasanya bermain dalam 2 mode yakni adu lama dan adu tikam. Dalam adu lama, gasing yang paling lama berputar itulah yang keluar sebagai pemenang. Sedang dalam adu tikam, satu gasing di mainkan terlebih dahulu baru kemudian lawan akan melemparkan gasingnya hingga mengenai gasing yang sedang berputar, dan yang bisa bertahan adakah

Ada beberapa jenis permainan gasing, yakni :

\section{a. Gasing Balanga}

Gasing Balanga juga merupakan jenis gasing tradisional Suku Dayak khas Kalimantan Tengah yang sering dipermainkan dalam tradisi "Bagasing". Jika pada Gasing Pantau mampu berputar lebih lama serta mengeluarkan bunyi yang nyaring, maka tidak demikian halnya dengan Gasing Balanga, gasing jenis Balanga ini adalah gasing yang umumnya dibuat dan dimainkan untuk tujuan diadu dengan gasing lain.

Tradisi mengadu Gasing Balanga ini dikenal warga masyarakat Dayak di Kalimantan Tengah dengan sebutan Batikam yakni mengadu ketahanan Gasing Balanga saat satu sama lain saling bersentuhan. Dalam kegiatan Batikam ini tidak jarang salah satu gasing akan pecah atau terbelah akibat benturan yang sangat keras. Gasing yang terjatuh, keluar dari arena permainan, apalagi sampai terpecah maka secara otomatis akan menjadi pihak yang kalah. Bentuk Gasing Balanga menyerupai 
sebuah tempayan atau dalam Bahasa Dayak Kalteng dikenal dengan istilah "Balanga". Ukuran Gasing Balanga atau gasing aduan ini biasanya memiliki diameter lingkaran sekitar $9 \mathrm{Cm}$ dan tinggi sekitar 7 Cm.

b. Gasing Pantau

Gasing Pantau merupakan satu diantara jenis gasing tradisional khas Provinsi Kalimantan Tengah, Dalam budaya masyarakat Dayak Kalteng tradisi memainkan gasing ini dikenal dengan istilah "Bagasing". Gasing Pantau adalah gasing yang dimainkan sedemikian rupa agar dapat berputar dalam waktu yang cukup lama. Ciri khas Gasing Pantau yang membedakannya dengan jenis gasing tradisional khas Kalteng lainnya yakni Gasing Balanga adalah Gasing Pantau mampu mengeluarkan bunyi.

Perpaduan antara lamanya perputaran gasing pada suatu poros dengan dinamika nada yang dikeluarkan oleh Gasing Pantau inilah yang membuat jenis gasing ini cukup menarik dan sering diperlombakan pada berbagai festival seni dan budaya Suku Dayak. Gasing Pantau yang mampu berputar lebih lama dan mengeluarkan bunyi yang nyaring biasanya akan keluar sebagai pemenang.

\section{Balap Egrang}

a. Nama permainan

Egrang : permainan anak tradisional khas kalteng yang terbuat dari bambu dengan panjang 2 meter kemudian diberi pijakan untuk kaki. Permainan ini mengandalkan keseimbangan agar dapat berdiri diatas alat ini.

b. Latar belakang sejarah/sosial

Seperti egrang pada umunya di Indonesia. Para pemain egrang pun beragam, mulai dari yang anakanak hingga dewasa.

c. Alat permainan dan cara bermain

Egrang terbuat dari bambu dengan panjang 2 meter sebesar lengan orang dewasa kemudian diberi pijakan untuk kaki. Permainan ini mengandalkan keseimbangan agar dapat berdiri diatas alat ini.

\section{Tembak Tutus}

a. Nama permainan

Tembak tutus adalah nama sebuah permainan masyrakat kalteng, menurut informasi permaianan ini berasal dari kawasan sungai kahayan dan kapuas. Tembaka tutus berasal dari bahasa dayak ngaju yang terdiri atas dua kata, yaitu tembak dan tutus. Tembak artinya bedil dan tutus berarti tusuk atau tekan. Jadi temabak tutus adalah nama permainan yang terbuat dari bambu yang dapat mengeluarkan bunyi letupan.

b. Latar belakang sejarah

Menurut informasi orang-orang tua, permainan ini lebih dulu dikenal dikawasan sungai kahayan dan kapuas. Bahkan boleh dikatakan permaianan ini berasal dari daerah tersebut dan sekarang sudah menyebar luas ke pelosok kalteng.

c. Deskripsi Permainan

Perang-perangan dengan tembak tutus biasanya memerlukan suatu kelompok dan setiap kelompok terdiri dari 5 atau 6 orang. Pesertanya berusia antara 10 - 15 tahun. Mereka membuat sendiri alat permainan ini. Permainan ini terbatas pada laki-laki saja, anak-anak wanita memang tidak cocok memainkannya.

d. Perlengkapan Permainan/Alat

Alat yang digunakan hanya berupatembak tutus dan pelurunya. Tembak tutus terbuat dari bambu kecil, kira-kira sebesar ibu jari. Bambu tersebut dipotong kurang lebih $30 \mathrm{~cm}$ dan hanya dipakai ruasnya saja untuk membentuk loop atau laras. Kemudian untuk padanannya dibuat yang disebut tutus. Tutus ini adalah alat untuk menekn peluru didalam laras tadi. Bambu penekan dibuat dari bmbu yang dibelah dan diraut halus. Setelah itu dibuat pegangannya (ulu).

Alat yang lain lagi adalah pelurunya. Peluru biasanaya buah kayu yang ukurannya kecil. Ada dua macam jenis buah yang biasa untuk peluru, yaitu buah uei nyamei dan buah sampaheneng. Buah-buahan ini biasnaya berukuran hampir sama sehingga gampang masuk kedalam lubang bambu laras. ini digunakan untuk

Dipublikasikan Oleh : 
perang-perangan, Sekaranga pelurunya dengan menggunakan peluru yang terbuat dari kertas, buah mesisin atau apa saja yang kecil dan keras.

Olahraga atau permainan tradisional memiliki banyak manfaat yang baik untuk perkembangan anak karena fisik dan emosi anak terlibat langsung sehingga dapat mempengaruhi pertumbuhannya. Dan apabila permainan modern dikombinasikan dengan permainan tradisional maka akan memberikan manfaat yang saling melengkapi bagi perkembangan anak, karena dalam permainan modern anak mendapat manfaat yang bersifat fisik, psikologis, dan aspek sosial. Adapun manfaat dari permainan tradisonal yang dapat mempengaruhi perkembangan anak adalah:

1. Melatih Konsentrasi, Fokus dan ketepatsan pada anak Contohnya dalam permainan Menyipet(menyumpit), pada permainan Menyipet ini melatih otak kiri anak dan melatih anak menggunakan Konsentrasi, Fokus dan ketepatan agar dapat Menembak sasaran/musuh dengan tepat sasaran.

2. Mengembangkan kecerdasan emosi pada anak Contohnya dalam permainan Bagasing, pada permainan Bagasing ini anak dilatih mulai dari proses pembuatan Gasing, yang mana sisinya harus seimbang agar bisa Berputar, dan saat memutarnya anak dituntut untuk sabar mencari arah yang tepat untuk memutar dan menabrakanya ke gasing lawan, dan menggerakkan tali gasing dengan gerakan yang tepat agar Pukulanya keras dan berputar lama.

3. Mengembangkan kecerdasan intelektual dan Strategi pada anak Contohnya dalam permainan Tembak Tutus, pada permainan tembak tutus ini melatih otak kiri anak dan melatih anak menggunakan strategi agar dapat Menembak sasaran/musuh lebih banyak dari lawan.

4. Meningkatkan kemampun bersosialisasi Contohnya pada permainan Sepak Sawut, permainan yang bersifat kelompok ini memberi kesempatan pada anak untuk bersosialisasi. Selain kebersamaan, anak diajarkan untuk mentaati peraturan, bergiliran, dan juga solidaritas dalam bemain.

5. Melatih kemampuan motorik Contohnya pada permainan Balap Egrang, ketika anak meloncat dengan satu kaki dan anak berusaha untuk menyeimbangkan tubuhnya dan loncatan yang dilakukan itu baik untuk metabolisme tubuh anak.

Perlombaan Olahraga Tradisional ini dilakukan 1 Tahun sekali bertepatan dengan Ulang Tahun Kabupaten Katingan dan sangat meriah dikarenakan hadiah yang cukup besar.

Diatas dijelaskan manfaat manfaat permainan tradisional yang bagus untuk perkembangan anak, meskipun sudah berkurang sarana maupun prasarana untuk bermain, kita sebagai generasi muda yang pernah mengalami masa kecil dan pernah memainkan permainan tradisional tersebut, memiliki kewajiban untuk meneruskan warisan budaya ini kepada generasi selanjutnya, dengan begitu anak-anak di masa yang akan datang dapat merasakan bermain permainan tradisional dan tumbuh menjadi anak yang cerdas dalam menjalani kehidupannya ketika dewasa.

\section{SARAN}

Agar HBTM menjadi ramai dan dikunjungi lebih banyak orang harus diadakan lagi promosi kesekolahsekolah TK, SD, SMP, SMA, dan Perguruan Tinggi ini akan mendongkrak jumlah pengunjung yang nantinya jg akan memperkenalkan kelebih banyak orang tentang Olahraga TradisionalDi Kalimantan Tengah. Selain itu pihak Pemerintah setempat juga harus sering membuat event atau pertandingan Olahraga Tradisional minimal 1 tahun ada 2 kali pertandingan atau acara agar banyak masyarakat ikut berlatih dan nantinya akan ikut bertanding karena disponsori oleh pemerintah setempat.

Untuk menjaga kelestarian bangunan fisik ataupun budaya Lokal di Rumah Betang pihak HBTM dan Masyarakat harus menjaga dan melestarikan budaya serta ramah dan melayani pengunjung yang datang ke HBTM baik lokal ataupun mancanegara.

\section{REFERENSI}


1. Sirnayatin, 2017. "Membangun Karakter Bangsa melalui Pembelajaran Olahraga Tradisional dan Rekreasi" Jurnal SAP. 1 (3) : 312 - 321

2. Tukidi. 2011. Membangun Karakter Bangsa di Tengah-Tengah Budaya Global. Jurnal Forum Ilmu Sosial, 1 (38) : $44-54$.

3. Hamidah, N. dan T.W. Garib. 2014. "Studi Arsitektur Rumah Betang Kalimantan Tengah". Jurnal Arsitektur Melayu dan Lingkungan. 1 (2) : 19 - 35.

4. Suwarno. 2017. "Budaya Huma Betang Masyarakat Dayak Kalimantan Tengah dalam Globalisasi : Telaah Konstruksi Sosial". Lingua 14 (1) : $89-102$.

5. Rusan, A.S. 2002. Olahraga TradisionalKalimantan Tengah. Propinsi Kalimantan Tengah. Palangka Raya.

6. Nazir, Muhammad. 2003. Metode Penelitian. Ghalia Indonesia. Jakarta

7. Bovy, M.B. \& Lawson, F., 1997. Tourism and Recreation Development. Massachusets: CBI Publishing Company.

8. Wing Haryono.2000. Pariwisata Rekreasi dan Entertainment. Jakarta

9. KEMNDIKBUD.2005. Balai Pengembangan Pendidikan Luar Sekolah dan Pemuda (BP-PLSP)

10. Wijayanti, 2017. Kurikulum 2013. KEMENDIKBUD.Jakarta

11. James Danandjaja,1987. Permainan Tradisional Indonesia 